\title{
Editors' Introduction: JBS 53, no. 4 (October 2014)
}

\section{Brian Cowan \\ Elizabeth Elbourne}

\section{FORUM: RETHINKING THE ENGLISH REVOLUTION}

The Journal of British Studies has long been concerned with explaining how the civil wars, the regicide, and the post-monarchical Cromwellian regimes of the midseventeenth century constituted an "English Revolution." From the debates in the 1960s between J. H. Hexter, Lawrence Stone, and David Underdown to the more recent works of Andrew Hopper, Jason Peacey, and David Como, the English Revolution has remained a topic of central interest for contributors to this journal. ${ }^{1}$ In the 1980s and 1990s, the provocative works of Mark Kishlansky played a particularly important role in contributing to the revisionist debates over the extent to which the civil war era should be understood to be a modern revolution or perhaps just the last of a long line of baronial revolts against the crown. ${ }^{2}$ Revisionism has more recently given way to post-revisionism, and the maturity of the post-revisionist paradigm has been demonstrated in our recent forum on early Stuart political history. ${ }^{3}$ Seventeenth-century history is no longer dominated by one major debate in which sides are taken and lines of demarcation drawn, or at least attempted. Instead, the field revels in its diversity and the diminished contentiousness arguably allows for a more nuanced understanding of the period to flourish.

The four articles in this forum present a snapshot of some of the diverse approaches to the history of the English revolution active today. Each was submitted to the journal independently, but we have gathered them together in this issue in order to showcase some current trends in the field. The problems of political identity construction (and reconstruction) in an age of civil war, and the tenuous, but insistent, legality of the post-regicidal revolutionary regimes are two major themes that emerge from these studies. Discourse analysis of political language, whether deployed by

${ }^{1}$ J. H. Hexter, “The English Aristocracy, Its Crises, and the English Revolution, 1558-1660," Journal of British Studies 8, no. 1 (Nov. 1968): 22-78; Lawrence Stone, "Postscript to Eight Hundred and Forty-One Pages," Journal of British Studies 8, no. 1 (Nov. 1968): 79-82; David Underdown, "The Independents Again," Journal of British Studies 8, no. 1 (Nov. 1968): 83-93; Andrew Hopper, "The Self Fashioning of Gentry Turncoats during the English Civil Wars," Journal of British Studies 49, no. 2 (April 2010): 236-57; Jason Peacey, "Print, Publicity, and Popularity: The Projecting of Sir Balthazar Gerbier, 1642-1662," Journal of British Studies 51, no. 2 (April 2012): 284-307; and David Como, "Print, Censorship, and Ideological Escalation in the English Civil War," Journal of British Studies 51, no. 4 (Oct. 2012): $820-57$

${ }^{2}$ Mark Kishlansky, "Consensus Politics and the Structure of Debate at Putney," Journal of British Studies 20, no. 2 (Spring 1981): 50-69; Kishlansky, "Saye No More," Journal of British Studies 30, no. 4 (September 1991): 399-448.

${ }^{3}$ Brian Cowan and Elizabeth Elbourne, "Editors' Introduction," Journal of British Studies 52, no. 2 (April 2013): 285-89. 
parliamentary elites or by plebian Londoners, figures prominently in the articles by Thomas Leng and Caroline Boswell, respectively. John M. Collins uses legal history to throw new light on the administration of justice during the civil wars and interregnum. Mark Williams's article attests to the continuing strength of the interest in the history of royalism that has developed in post-revisionist historiography of the revolution.

Thomas Leng's “The Meanings of 'Malignancy': The Language of Enmity and the Construction of the Parliamentarian Cause in the English Revolution" introduces a new concept for understanding how the political divisions of the early 1640s ultimately led to the emergence of two clearly opposed sides that were willing to fight a war with one another. He argues that the label "malignant" and the accompanying concept of malignancy were not just synonyms for royalists and the royalist cause but were, rather, means of invoking the need to expel from the body politic those people who conspired to divide the king from his parliament. Fighting malignancy, and vanquishing the malignants, became a defining feature of the construction of a sense that there was a parliamentary cause that required defending and was worth fighting for.

In "Hidden in Plain Sight: Martial Law and the Making of the High Courts of Justice, 1642-60," John M. Collins also explores an often overlooked aspect of the revolutionary experience in England: the establishment of High Courts of Justice as a means of continuing the exercise of a form of prolonged martial law in England even after the cessation of armed hostilities between the royalist and parliamentarian armies. Collins argues that the commonwealth and protectorate regimes of the 1650s used the High Courts of Justice as means of scaring potential enemies of the regimes into obedience and because they feared that jury nullification in an ordinary court of law would diminish the threat potential of prosecution for treason. While the High Courts may not have been fair, they did follow a form of legal procedure. The experience of and elaboration upon the codes of martial law were distinctive aspects of the English Revolution.

With Caroline Boswell's "Provoking Disorder: The Politics of Speech in Protectorate Middlesex," we are taken to the streets of revolutionary London in the 1650s and are allowed to witness the ways in which ordinary Londoners expressed themselves politically. Her article studies the micro-politics of everyday life by looking at the creation and implementation of the Cromwellian Protectorate's ordinance in 1654 that prohibited dueling along with any other language or gestures that might provoke conflict. While the ordinance sought to restore social peace to a society still recovering from the turmoil of civil war, Boswell argues that it actually exacerbated the problem. As all sorts of interpersonal conflicts or expressions of discontent were now potentially deemed "provocative," the relationship between disruptive speech and political instability was in fact reinforced.

Whereas the forum begins with the construction of a parliamentarian identity, it concludes with a study of royalism. In "The Devotional Landscape of the Royalist Exile, 1649-1660," Mark Williams explores the experience of exile for royalists during their decade of exclusion from power in the 1650s. He places religion at the heart of this experience. English royalism was defined in many respects by a devotion to defending the episcopal Church of England with the king as its supreme governor, but this Protestant devotion was challenged by the experience of exile abroad during the interregnum, often in the midst of Roman Catholic hosts, allies, and 
fellow royalist supporters. The diversity of the royalist cause, embracing as it did Catholics and Protestants, Irish and Scots, as well as English supporters of the king, when coupled with the enforced mobility produced by the experience of exile, proved to be a serious challenge to the maintenance of a unified sense of purpose or identity for interregnum royalists.

Taken together, these four articles leave us with a sense of the fragility of identities, loyalties, legalities, and polities that were continually put under extraordinary pressure during the 1640s and 1650s. Traditional allegiances, established laws, and of course the endurance of the monarchical state were all questioned and reconstituted during these revolutionary decades. Each of these articles takes great care to illuminate the heterogeneity of beliefs and allegiances that so perplexed and bedeviled the regime of King Charles I and the Commonwealth and Protectorate that succeeded it. The articles in this forum do not comprise the elements of a new school of interpretation, but rather demonstrate the continued vitality of the history of the English Revolution in the early twenty-first century.

Of the remaining four articles in this issue, the first two are studies in movement: one focuses on British imperial history in the 1760s, and the other on the peripatetic life of Queen Caroline's adopted child, William Austin. The second two articles illustrate the value of close readings, with one re-examining the military strategy of the Easter Rebellion of 1916 in the light of political struggles in Dublin, and the other giving a rich reading of the individual lives of "scholarship boys" in post-war Britain.

David Stiles is interested in debate in Britain about how best to fight Bourbon Spain in the waning years of the Seven Years War, both for the debate itself and for what it reveals about the capacity of the British state to absorb competing views of empire. In "Arresting John Entick: The Monitor Controversy and the Imagined British Conquests of the Spanish Empire," Stiles examines the arrest of dissident journalist John Entick over his criticism of the Bute administration's handling of the peace treaty of 1763. The case raised important issues around the freedom of the press and can be read against the much better known example of John Wilkes' confrontations with the state in the same time period. Stiles claims that Entick's ultimate victory in court was an important moment in guaranteeing space for dissent on imperial policy in Britain. The article also explores ways in which Bourbon Spain existed as an imaginative counterfoil to the supposedly more virtuous British Empire in the mind of many British commentators.

In "Adoption, Narrative, and the Nation, 1800-1850: The Case of William Austin," Eric Walker traces the strange life of William Austin. Despite having living parents, Austin was taken in by Queen Caroline as a baby. In an ambiguous adoption into royalty, Austin was treated by Caroline as her son and traveled in her entourage, first as a child and then as a young man, as she moved restlessly from one place to another over the course of her long estrangement from her husband, the future George IV. Walker uses the life of Austin as a springboard to examine child adoption in the Regency period and the fluidity of "family." Austin's association with Caroline took place on a vast stage, before a public fascinated by political intrigue and high-stakes scandal. This is also, therefore, a story about the politics of celebrity and the public life of the intimate. 
In "Socialist Republican Discourse and the Easter Rising, 1916: The Occupation of Jacob's Biscuit Factory and the South Dublin Union Explained," Lauren Arrington sets herself the task of explaining why the Republican forces during the 1916 Easter Rising chose to occupy two seemingly militarily unattractive sites, a workhouse union and a biscuit factory. Arrington painstakingly reconstructs the tensions between socialist Republicans involved in the Rising, notably labor leader James Connolly and the Irish Transport and General Workers' Union, from which the Citizens Army grew, and the administrations of both Jacob's Biscuit Factory and the South Dublin Union. Arrington thus shows that these were carefully chosen sites with symbolic political value. Their occupation reminds us of the importance of socialist politics to the Easter Rising, and sheds important new light on the aims of rebels, as well as tensions within the movement. Among the innovations of the article is Arrington's close reading of the popular socialist press, notably the Irish Worker, the newspaper of the Irish Transport and General Workers' Union. Discourse analysis shows how a flexible Republican language could accommodate diverse political perspectives.

Finally, D. L. LeMahieu returns to some of the themes of biography and history that we explored in the previous issue of the Journal of British Studies. "Scholarship Boys' in Twilight: The Memoirs of Six Humanists in Post-Industrial Britain" examines the memoirs of six "scholarship boys"-clever young men from working-class backgrounds who became eminent intellectuals of one kind or another in post-war Britain. This was the first generation of "scholarship boys." LeMahieu tells their stories empathetically but not uncritically, examining in the process the very nature of memoir writing and the workings of memory through time. He also uses these memoirs to think about generational experience and the generational nature of post-war humanism. In the end, he movingly turns to once-young men looking back on their lives and confronting death. The essay is an experiment in using the close reading of a handful of selected memoirs as a way into the larger experiences of a particular cohort of intellectuals.

Our next issue will begin with the NACBS presidential address delivered by Dane Kennedy at the 2013 annual meeting in Portland, Oregon, on imperial history and its uses through time. The issue will also include an article on ideas about Satan in early modern Scotland as well as a new look at the relationship between John Milton and Oliver Cromwell. An essay on the dissection of the bodies of executed convicts asks why parliamentary efforts to extend the practice and to provide a regularized stream of bodies for doctors failed. A methodologically innovative article on late nineteenthcentury electoral politics uses the quantitative analysis of language to gauge the effectiveness of Joseph Chamberlain's "unauthorized campaign" in the hotly contested post-reform campaign of 1885, while a further article examines public policy concerns regulating charity fund-raising in Victorian Britain. Two articles focused on the twentieth century will conclude the issue: one an ambitious longitudinal study of diary keeping and the use of diaries by historians, and the other an analysis of secularization, the decline of empire, and the collapse of a sense of a Christian national identity in the post-war period. 